\title{
Amyloidogenic Peptides in Human Neuro-Degenerative Diseases and in Microorganisms: A Sorrow Shared Is a Sorrow Halved?
}

\section{Kristina Endres}

Department of Psychiatry and Psychotherapy, University Medical Center Johannes Gutenberg-University Mainz, 55131 Mainz, Germany; Kristina.endres@unimedizin-mainz.de; Tel.: +49-6131-17-2133

Received: 28 January 2020; Accepted: 17 February 2020; Published: 19 February 2020

\begin{abstract}
The term "amyloid" refers to proteinaceous deposits of peptides that might be generated from larger precursor proteins e.g., by proteolysis. Common to these peptides is a stable cross- $\beta$ dominated secondary structure which allows self-assembly, leading to insoluble oligomers and lastly to fibrils. These highly ordered protein aggregates have been, for a long time, mainly associated with human neurodegenerative diseases such as Alzheimer's disease (Amyloid- $\beta$ peptides). However, they also exert physiological functions such as in release of deposited hormones in human beings. In the light of the rediscovery of our microbial commensals as important companions in health and disease, the fact that microbes also possess amyloidogenic peptides is intriguing. Transmission of amyloids by iatrogenic means or by consumption of contaminated meat from diseased animals is a well-known fact. What if also our microbial commensals might drive human amyloidosis or suffer from our aggregated amyloids? Moreover, as the microbial amyloids are evolutionarily older, we might learn from these organisms how to cope with the sword of Damocles forged of endogenous, potentially toxic peptides. This review summarizes knowledge about the interplay between human amyloids involved in neurodegenerative diseases and microbial amyloids.
\end{abstract}

Keywords: amyloid; Alzheimer's disease; biofilm; neurodegeneration; microbiota; Parkinson's disease

\section{Introduction}

Amyloidogenic peptides or proteins are well known to be the main culprit of various human diseases, but more recently, several of these proteins with physiological function have been identified also in humans (reviewed in [1]). One prominent example is the pigment cell-specific pre-melanosomal protein (PMEL). Fibrils of this protein might offer a scaffold for highly reactive melanin intermediates and thereby protect the synthesizing cells [2]. A second example of functional amyloids is the RIP1/RIP3 necrosome signaling complex [3]. Interestingly, RIP1/RIP3 seem to mediate the necroptosis of dopaminergic neurons in a murine Parkinson's disease (PD) model [4] and PMEL amyloid formation is based on cleavage by BACE-2 and $\gamma$-secretase [2], both enzymes also capable of cleaving the Alzheimer's disease (AD)-relevant amyloid precursor protein (APP).

Out of the known amyloidogenic proteins found in humans, 37 are correlated to diseases [5] such as systemic primary amyloidosis caused by monoclonal light chains (AL) or hereditary ALs such as those caused by ApoA1 or lysozyme [6,7]. While only about one third of all amyloidoses leads to proteinaceous deposits in the central nervous system, these diseases represent the most common forms of amyloid-derived disorders. AD and related dementias for example, affected more than 40 million people in 2016 [8] and there is an estimated number of more than six million PD patients world-wide [9]. The proteins contributing to these neurodegenerative diseases are well known and have been identified 
decades ago (see Table 1). For AD, APP gives rise-via subsequent proteolytic processing-to the amyloid- $\beta$ peptide (Figure 1A) while in PD $\alpha$-synuclein represents the amyloidogenic compound. For familial cases of both and other protein-deposit-based diseases, heredity of mutated variants of the amyloid-encoding genes or genes encoding respective processing enzymes are key to pathogenesis. The vast majority of cases still though is designated sporadic, indicating that the underlying mechanism has not been identified yet.

Table 1. Human amyloidoses with manifestation in the central nervous system (neurodegenerative disorders). While some proteins/peptides represent a characteristic hallmark for just one disease, some are also found in various diseases such as hyperphosphorylated Tau protein.

\begin{tabular}{ll}
\hline \multicolumn{1}{c}{ Name of Peptide or Protein } & \multicolumn{1}{c}{ Disease } \\
\hline$\alpha$-synuclein & $\begin{array}{l}\text { Parkinson's disease (PD) } \\
\text { Lewy body disease } \\
\text { Multiple systemic atrophy }\end{array}$ \\
\hline Amyloid- $\beta$ & Alzheimer's disease (AD) \\
\hline Ataxin & Spirocerebellar ataxia \\
\hline F-box protein 7 (FBXO7) & Parkinson's disease (PD)/Alzheimer's disease (AD) \\
\hline Prion protein (PrPsc) & Transmissible spongiform encephalopathy (TSE) \\
\hline \multirow{2}{*}{ Tau (hyperphosphorylated) } & $\begin{array}{l}\text { Frontotemporal dementia (FTD) } \\
\text { Alzheimer's disease (AD) }\end{array}$ \\
& $\begin{array}{l}\text { Niemann Pick disease } \\
\text { Progressive supranuclear palsy } \\
\text { Amyotrophic lateral sclerosis (ALS) }\end{array}$ \\
\hline \multirow{2}{*}{ Transactive response DNA binding protein 43 } & $\begin{array}{l}\text { Amyotrophic lateral sclerosis (ALS) } \\
\text { Alzheimer's disease (AD) }\end{array}$ \\
\hline FDP43) & $\begin{array}{l}\text { Frontotemporal lobar degeneration with ubiquitin-positive } \\
\text { inclusions (FTLD-U) }\end{array}$ \\
\hline Superoxide dismutase 1 (SOD1) & Amyotrophic lateral sclerosis (ALS) \\
\hline Huntingtin (with polyQ tract $>33$ residues) & Huntington's disease \\
\hline
\end{tabular}

Progressively, relevance of microbial commensals came into focus as a possible contributing factor to neurodegenerative disorders (for concise reviews see [10-12]). Increasing number of reports provide correlative studies on altered microbiota in those kinds of diseases, but the outcome is quite controversial and evidence-based investigations are still scarce. Scheperjans and colleagues pinpointed this clearly by entitling a 2018 review with "The Gut and Parkinson's Disease: Hype or Hope?" [13]. However, it seems that changes in at least some bacterial commensals have been consistently found. For PD, increased relative abundance of representatives from the genera Akkermansia, Lactobacillus, and Bifidobacterium and reduced abundances of Prevotella, Faecalibacterium, and Blautia have been shown [14-18]. For AD, Ruminococcus and S24-7 seem to be occasionally decreased while Odoribacter and Blautia as well as Alistipes have been shown to be increased in human and mouse model studies (summarized in [19]). Nevertheless, these are still only observational studies and lack functional conjunction between microbiota composition and pathogenesis. More recent investigations using e.g., fecal material transplants in mouse models might give deeper insight into mechanisms: the gut microbiota from a PD mouse model initiated motor impairment and decrease in striatal neurotransmitters in wild type mice while transfer of fecal material from wild type mice to PD mice ameliorated hallmarks of disease such as inflammatory status [20]. A daily application of fecal material from wild type mice was also found to reduce symptoms in the APPPS1 AD model mouse strain: performance in the Morris Water Maze task (a test reporting on learning and memory) increased significantly and amyloid- $\beta$ brain levels were reduced by nearly $50 \%$ [21]. 
How the microorganisms can contribute to amelioration or aggravation of disease is still enigmatic. It is tempting to assume that bacterial metabolites such as short chain fatty acids are key players. Their effect has been proven in many studies (e.g., [22,23]). Another option is provided by the fact, that bacteria, fungi, and viruses are also capable of producing amyloidogenic proteins or peptides (see Figure 1B). Here in this review, focus was laid on the potential interplay of those microbial agents and their producers with the proteins and peptides underlying human neurodegenerative amyloidoses.

A

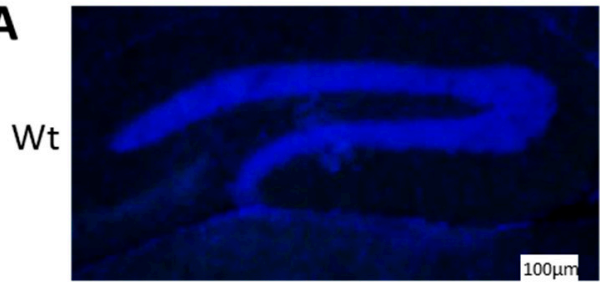

$\mathrm{AD}$

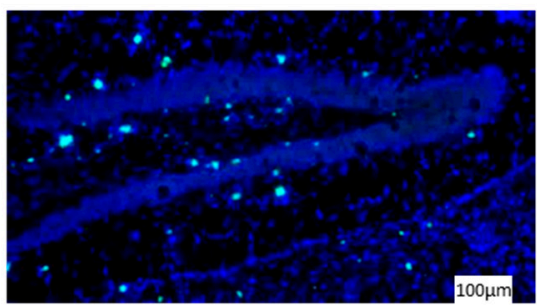

B

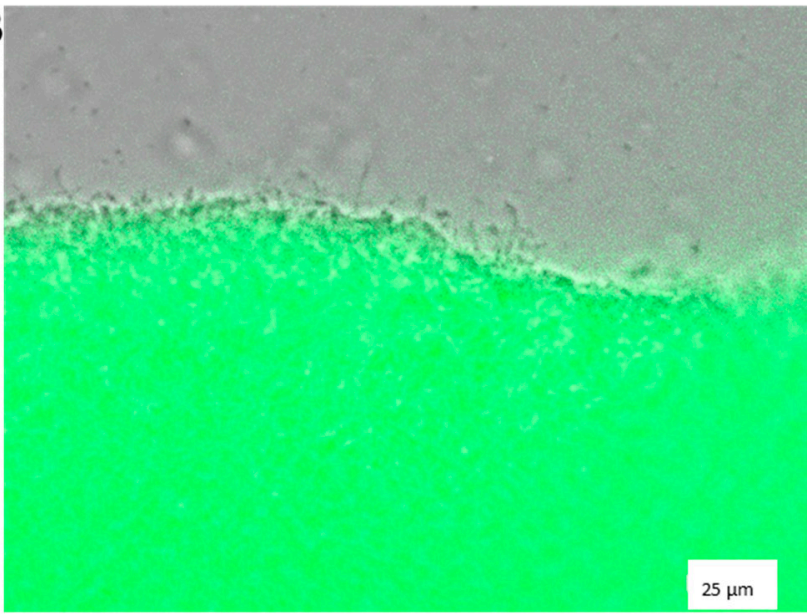

Figure 1. Amyloid deposits in the brain of an AD mouse model and in Escherichia coli biofilm layer. (A) Sagittal sections of murine brain were fixed with $4 \%$ PFA and amyloid plaques stained with ThT (turquois spots; merged with blue counterstain of cell nuclei by DAPI). The region of hippocampus of an AD model mouse $(5 \times \mathrm{FAD},[24])$ is shown in comparison to a wild type mouse brain (Wt). (B) E. coli bacteria (DH5 $\alpha$ ) were grown for $48 \mathrm{~h}$ on YESCA agar and the biofilm stained with ThT (shown is a merge of bright field and green fluorescent channel).

\section{The Impact of Host Amyloidogenic Peptides on Microbial Commensals}

Occurrence of bacteria in close surrounding to amyloid deposits in the brain of the human host has been demonstrated. For example, LPS and pili proteins of E. coli have been found in grey and white matter samples of Alzheimer's disease patients while control samples remained negative in western blotting experiments [25]. Several periodontal pathogen spirochetes such as Treponema medium were additionally detected by PCR or antibodies or have been cultivated from AD brain material. For example, Borrelia burgdorferi was found in $\frac{1}{4}$ of all investigated AD cases (for an overview see [26]). For PD such data are-to this author's knowledge-not available yet. However, especially for PD early $\alpha$-synuclein deposits have been detected in the gut (for a critical review on the "gut first" hypothesis see: [27]). Moreover, APP positive staining and amyloid- $\beta$ deposits have also been found in the gut of AD model mice and cases of human disease $[28,29]$. Therefore, a direct interaction between the amyloids derived by the host and those produced by bacterial commensals can be envisioned in different sites of the body.

The impact of human amyloidogenic peptides on microbes has been investigated so far for $\alpha$-synuclein and amyloid- $\beta$ peptides: they seem to act as antimicrobial peptides (AMPs) at least towards some microorganisms. Using recombinant $\alpha$-synuclein-derived peptides of different lengths, a minimal inhibitory concentration (MIC) of $0.2 \mu \mathrm{M}$ was found for tested bacteria (e.g., E. coli, Staphylococcus aureus) and MICs of 0.4 to $3.2 \mu \mathrm{M}$ for fungal organisms such as Candida albicans [30]. A rhodamine-labelled peptide could be localized to E. coli cell membrane and C. albicans cytoplasm, indicating a direct way of interaction. For E. coli, a dose-dependent influx of a non-membrane-penetrant dye in cells with $\alpha$-synuclein incubation was demonstrated, suggesting a membranolytic mechanism. Comparably, Escherichia faecalis and $S$. aureus also bound to and were agglutinated in the presence of amyloidogenic amyloid- $\beta$ species (e.g., A- $\beta$ X-42, [31]). Interestingly, the less toxic and less 
aggregation-promoting peptide species amyloid- $\beta$ 1-40 and 2-40 did not reveal these properties. Moreover, the observed antimicrobial effect was also restricted to the highly amyloidogenic peptide variants. Additionally, incubation of $C$. albicans with homogenates from temporal lobe of AD cases resulted in reduced growth capability as compared to homogenates from healthy controls [32] while no difference occurred when administering cerebellar homogenates. The cerebellum is a tissue that is not majorly affected by degenerative processes in $\mathrm{AD}$ [33]. Together with the correlation of amyloid- $\beta$ burden in tissue and growth reduction of the yeast cells, this underlines the antimicrobial property of the amyloidogenic peptide characteristic for AD.

Mice genetically modified to represent an aggressive familial onset type of AD (therefore also designated $5 \times \mathrm{FAD}$ ) were protected from Salmonella typhimurium infection after single intracranial injections [34]. This was demonstrated by reduced weight loss and bacterial brain load as compared to wild type controls. Similarly, C. albicans infections of Caenorhabditis elegans and cultured cell lines (H4-N or $\mathrm{CHO}-\mathrm{N}$ ) were ameliorated by amyloid- $\beta$ peptides. Therefore, it has been speculated that the long time unidentified physiological function of the amyloidogenic peptides characteristic for neurodegenerative diseases might be found in antimicrobial defense (see for example [35]). Nowadays, with our high hygiene standards, this weapon is possibly backfiring. Prolonged life time resulting e.g., in leakiness of the blood brain barrier (e.g., [36]) together with reduced risk of infection might be causative to neurodegenerative diseases in the aging brain.

Among many open questions, future investigations will have to clarify if an altered microbial community as observed in AD and PD (e.g., $[19,37])$ will react in the same manner to the toxic peptides as compared to a "healthy" community or if an adaptation is achieved that lastly might explain the altered microbial composition. In vitro investigations lacking the physiological surrounding of e.g., the gut with all its gradients (surface-lumen; stomach-large intestine) and highly defined parameters such as oxygen availability might explain the correlations only to a minor extend.

\section{Occurrence and Function of Amyloidogenic Peptides in Microbial Organisms}

Several non-pathological amyloids have been described so far such as in melanosomes [38], hormone-derived amyloids to confer storage within pituitary gland [39] or CRES amyloids as a component of the normal epididymal luminal sperm maturation [40]. Therefore, amyloidogenic peptides are not only linked to human diseases but occur with a distinct physiological function also in healthy conditions.

A recent review highlights the potential role of amyloids in the origin of life on Earth as these short aggregates are highly stable, can already form in prebiotic environment and might provide a basis for interaction with other polymeric structures such as RNA due to their repetitive character [41]. Therefore, their appearance in microbes, early settlers of our planet, seems highly plausible. Knowledge on their function is still restricted, however, when summarizing it, it seems that biofilm scaffolding and modification as well as attachment to membrane-surfaces are central (see Table 2). Biofilms are complex communities of bacteria grown on biotic (e.g., intestinal surface) or abiotic material (e.g., medical devices). When freely floating bacteria attach to surfaces, they start with a distinct expression program, resulting in production of exogenously deposited polysaccharides (firstly acknowledged by Costerton as biofilm-formation [42], Figure 2). They then also become progressively immobile (reviewed in [43]) and the surrounding matrix is completed by for example DNA (reviewed by [44]) and protein excretes such as amyloidogenic peptides. 
A

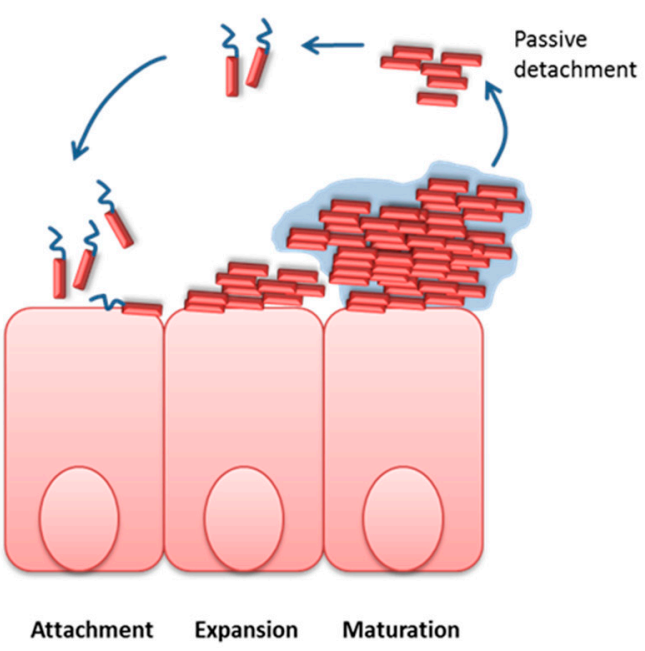

B

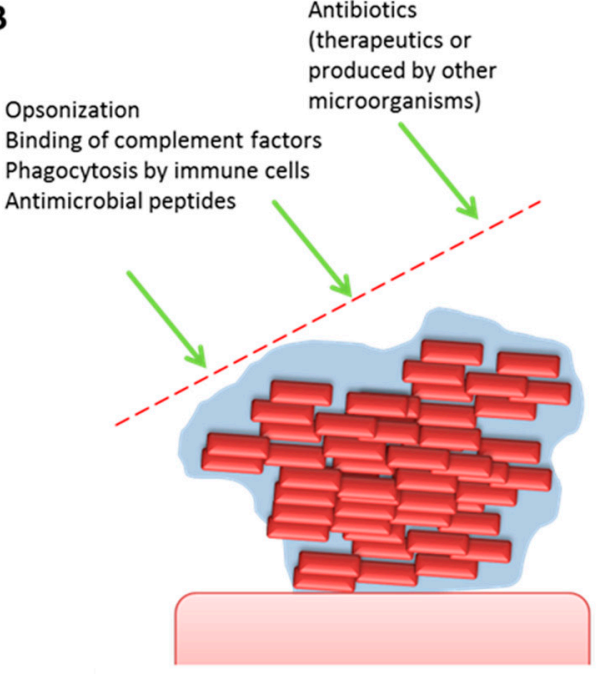

Figure 2. Biofilm formation on a biotic surface and protection against harms. (A) Bacterial biofilms form in three main steps: after initial attachment, bacteria expand and start to produce specialized components such as cellulose [45] to form a protective "slime" along with forfeiting motility. In a later phase, the mature biofilm allows detachment of clumps of cells or newly built cells to translocate to new areas of settling. Pore-building by PSMs (see Table 2) is assumed to play a major role in these events. (B) While one can imagine the biofilm to provide an ecosystem with restricted access to nutrition and space, it in contrast provides an especially protected area against attacks of the host immune system but also against exogenously added drugs or toxic compounds of other microbial species.

The most intensely studied example of bacterial amyloids are the curli fibers found in E. coli which also have been found in Salmonella, Citrobacter, Enterobacter (for example [46-48]), and at least theoretically in Proteobacteria, Bacteroidetes, Firmicutes, and Thermodesulfobacteria (homologous encoding genes have been identified, [49]). In response to environmental conditions such as $\mathrm{pH}$ or nutritional sources, the master regulator CsgD drives expression of an operon encoding for CsgA and B (e.g., [50]). The protein CsgA aggregates with support from CsgB into curli fibers that can be stained by Thioflavin T or Congo red (see Figure 1, [51,52]) and support binding of the bacteria to different surfaces and molecules such as abiotic material or fibronectin [53-55].

Staphylococcus epidermidis and S. aureus are the predominant colonizers of medical implants in the clinic and $S$. aureus is the leading cause of morbidity and mortality among healthcare-acquired infections (e.g., Meticillin-resistant S. aureus (MRSA), [56]). From 94 cefoxitin-resistant S. aureus isolates derived from human patients, 65 were positive for a specialized phenol soluble moduline (PSM) which has a positive impact on biofilm formation [57]. The family of the PSMs contributes to various virulent properties (e.g., toxicity against human T-cells, [58]) and their various functions might be explained by different amyloid structures depending on truncation of the peptide [59].

Not only bacteria but also fungi and viruses have been shown to possess functional amyloidogenic proteins. Adhesin Als3, found in C. albicans cell wall for example, seems to have a pivotal role in developing communities with Porphyromonas gingivalis in the human oral cavity. This shifts gene expression of $P$. gingivalis into a more virulent pattern and thereby probably promotes inflammatory periodontal diseases [60]. The VP4 protease from avibirnavirus that causes immunosuppression and mortality in young chickens [61], was found to form tubular structures which on one hand prevent premature cell death of the host cells at the early disease stage but support cytoskeleton disarrangement at later stage [62]. This indicates that several microbial organisms use amyloidogenic peptides or proteins to regulate or achieve virulent properties (for an overview see Table 2) and leads to the question if and how such microbial components may influence the host's own amyloidogenic structures. 
Table 2. Amyloidogenic proteins and peptides from microbial organisms. The indicated organism or family must not be imperatively the only organism producing the respective peptide or protein but was used in the underlying investigation. (nn: not known so far).

\begin{tabular}{|c|c|c|c|c|}
\hline $\begin{array}{c}\text { Name of } \\
\text { Organism/Family }\end{array}$ & $\begin{array}{c}\text { B = Bacterial } \\
\text { F = Fungal } \\
\text { V = Viral }\end{array}$ & $\begin{array}{c}\text { Name of Peptide or } \\
\text { Protein }\end{array}$ & Function & Reference \\
\hline B. burgdorferi & B & $\begin{array}{l}\text { Peptide designed from } \\
\text { outer surface protein A } \\
\text { (Osp)A }\end{array}$ & $\mathrm{nn}$ & [63] \\
\hline E. coli & B & RNA binding protein $\mathrm{Hfq}$ & $\begin{array}{l}\text { Interaction with biological } \\
\text { membranes, potentially } \\
\text { export of RNA }\end{array}$ & [64] \\
\hline E. coli & B & MinE & $\begin{array}{l}\text { Interaction with biological } \\
\text { membranes, lipid } \\
\text { redistribution }\end{array}$ & {$[65,66]$} \\
\hline E. coli & B & $\begin{array}{l}\text { Hydrogenase maturation } \\
\text { factor HypF (HypF-N) }\end{array}$ & $\begin{array}{l}\text { Permeabilization of } \\
\text { membranes }\end{array}$ & [67] \\
\hline Enterobacteriaceae & B & CsgB & Biofilm formation & {$[47,68]$} \\
\hline Gallibacterium anatis * & B & $\begin{array}{l}\text { Elongation factor-Tu } \\
\text { (EF-Tu) }\end{array}$ & Adhesion-like function & [69] \\
\hline Mannheimia haemolytica & B & $\begin{array}{l}\text { Amyloid-like protein } \\
\text { (ALP) }\end{array}$ & $\begin{array}{l}\text { Cell adhesion, biofilm } \\
\text { formation }\end{array}$ & [70] \\
\hline Mycobacterium tuberculosis & B & $\begin{array}{l}\text { Early secreted antigen } \\
\text { 6-kDa protein (ESAT-6) }\end{array}$ & Potentially pore-formation & {$[71,72]$} \\
\hline Pseudomonas aeruginosa & B & $\begin{array}{l}\text { Functional Amyloid in } \\
\text { Pseudomonas (Fap) C }\end{array}$ & Strengthening of biofilms & {$[73,74]$} \\
\hline S. aureus & B & $\begin{array}{l}\text { Phenol soluble modulins } \\
\text { (PSMs) }\end{array}$ & $\begin{array}{l}\text { Resistance of biofilms to } \\
\text { various dispersion agents }\end{array}$ & [75] \\
\hline S. aureus & B & $\begin{array}{l}\text { N-terminal leader } \\
\text { fragment of accessory gene } \\
\text { regulatory (Agr) D }\end{array}$ & $\begin{array}{l}\text { Seeding the amyloid } \\
\text { polymerization of PSM } \\
\text { peptides (in vitro) }\end{array}$ & [76] \\
\hline S. epidermidis & B & $\begin{array}{l}\text { C-repeat of Biofilm } \\
\text { associated protein (Bap) }\end{array}$ & $\begin{array}{l}\text { Potentially } \\
\text { bacteria-bacteria-adhesion }\end{array}$ & [77] \\
\hline C. albicans & $\mathrm{F}$ & $\begin{array}{l}\text { Agglutinin-like sequence } \\
\text { family } 3 \text { (Als3) }\end{array}$ & $\mathrm{nn}$ & [78] \\
\hline Saccharomyces cerevisiae & $\mathrm{F}$ & glucantransferase Bgl2 & $\begin{array}{l}\text { Assumed cell protection } \\
\text { against oxidative stress }\end{array}$ & [79] \\
\hline $\begin{array}{l}\text { Avibirnavirus infectious } \\
\text { bursal disease virus (IBDV) }\end{array}$ & V & Viral protease VP4 & $\begin{array}{l}\text { Reduction of cytotoxicity } \\
\text { of protease activity in host } \\
\text { cells }\end{array}$ & [62] \\
\hline Coronavirus & $\mathrm{V}$ & Peptide C6 & $\mathrm{nn}$ & [80] \\
\hline
\end{tabular}

\section{Impact of Microbial Amyloids on Host Health and Neurodegeneration}

Spreading of amyloidogenic material from a peripheral site such as the gut with its pleithora of commensals might not seem highly plausible at first sight. However, injection of AAV vectors encoding human $\alpha$-synuclein in the left vagus nerve in the neck of rats sufficed to allow propagation to the pons, midbrain and forebrain [81]. Thioflavin-S positive stain thereby indicated amyloidogenic aggregation in a small number of neurites. The vagal nerve is one of the major connections of the gut-brain-axis. Interestingly, vagal gut-brain sensory (afferent) signaling was required for hippocampal-dependent learning processes as demonstrated by partially vagotomized rats in a modified Barnes maze [82]. Vagal afferent information is first received in the brain within the medial nucleus of the solitary tract which projects towards many brainstem and forebrain sites $[83,84]$. The finding that it also affects 
hippocampus without having direct connection envisions the opportunity that also other brain regions might depend on afferent vagus nerve input.

Autopsy studies suggested that $\alpha$-synuclein-based Lewy body pathology initially occurs in the enteric nervous system (ENS) and from there proceeds to the dorsal motor nucleus of the vagus nerve. This was further supported by retrospective analysis of human patients which indicated that truncal vagotomy might be protective against PD [85]. By injecting pre-formed $\alpha$-synuclein fibers into the mouse gastric wall, Lewy-body-like structures were obtained in the dorsal motor nucleus [86]. This could be prevented by vagotomy. Even if no further caudo-rostral propagation of amyloidogenic particles was observed, this investigation describes a putative first step in development of a neurodegenerative disease starting from the gut. Comparably, entry of orally ingested prion proteins from the gut with subsequent spreading to the brain is possible [87]. Interestingly, infection of local Peyer's patches within the small intestine seems to be independent from endogenous cellular prion protein $\left(\mathrm{PrP}^{\mathrm{c}}\right)$ as shown in mice with epithelial deficiency of the protein in the lining of the small intestine [88]. Besides the vagus nerve, also other tissues might be implicated in further progression of amyloid spreading such as the olfactory epithelium, the mucosa of the oral cavity and the trigeminal nerve. Administering fluorescent amyloid- $\beta$ peptides e.g., to the nostrils of mice after mannitol-based relaxation of the blood-brain-barrier led already after $1 \mathrm{~h}$ to signals in tissue homogenates derived from the hippocampus and cortical regions [89]. Moreover, this was accompanied by impaired learning and memory performance as measured by fear conditioning and Morris water maze task.

Besides the impact that bacteria might exert via pro-inflammatory potential versus the host, a direct influence of their amyloids, for instance derived by biofilm formation, is plausible. Direct evidence for human patients is-to my knowledge-still lacking. However, feeding of curli-producing E. coli to a C. elegans model with muscular expression of $\alpha$-synuclein increased aggregation of these peptides in the worm [90]. Aged Fisher 344 rats exposed to the bacteria by gavage revealed induced aggregation of $\alpha$-synuclein in the striatum and the substantia nigra accompanied by astrogliosis and microgliosis as compared to animals inoculated with vehicle or curli-deficient-bacteria. In a recent report, this was further substantiated by mono-colonization of $\alpha$-synuclein overexpressing germ-free mice with curli-producing E. coli [91]. While colonization with a curli-deficient bacterial strain did not elicit motor impairment, beam traversal and pole descent were impaired in those animals inoculated with curli-producing E. coli. Similar results were obtained by administering the curli-producers on a complex fecal transplant background (human with low amount of curli-producers).

The N-terminal domain of HypF from E. coli (HypF-N) is also an amyloidogenic protein (see Table 2). Type A oligomers of HypF-N were found to colocalize with post-synaptic densities in primary rat hippocampal neurons [92]. Moreover, they inhibited CA1 hippocampal long-term potentiation in organotypic slices from rat. Intracerebral application of amyloid- $\beta$ peptides in rats leads to impaired learning and memory as found in Alzheimer's disease, e.g., assessed in the Morris water maze task (e.g., [93]). Interestingly, the intra-hippocampal injection of type A HypF-N oligomers in rats also resulted in similar memory impairment in the learning task [92], indicating that this bacterial amyloid can mimic synaptotoxicity of amyloid- $\beta$.

In sum, microbial amyloids seem to have the potential to affect human amyloid aggregation. If this holds true for a situation bearing physiological concentrations and parameters within the human body will surely be difficult to demonstrate.

\section{Therapeutic Strategies Derived from Microbes against Human Amyloidosis}

Probiotics have been suggested for therapeutic usage in regard to human neurodegenerative diseases such as AD. First reports indicate successful application in animal models: Lactobacillus plantarum, for example, was able to restore cognition and levels of acetylcholine esterase in the brain of a D-galactose-evoked AD-like rat model [94]. Similar results were obtained from investigations using genetic AD mouse models with Bifidobacterium breve strain A1 [95], SLAB51 (probiotic formulation, [96]) but also with Lactobacillus acidophilus, Lactobacillus fermentum, Bifidobacterium lactis, and Bifidobacterium 
longum in rodent sporadic AD models due to amyloid- $\beta$ injection [97-99]. As only one explorative intervention study reports on a small cohort of AD human patients [100], the usefulness in humans is still not proven. Additionally, the underlying mechanism has not been resolved. However, amyloids from microorganisms also might be target to this treatment as Lactobacillus helveticus is for example able to produce biosurfactants that are able to suppress biofilm formation from S. aureus [101]. Moreover, a modified functional amyloid from Pseudomonas (FapC) not only itself showed prolonged lag time for aggregation but additionally attenuated $\alpha$-synuclein fibrillation in vitro [102]. While the authors of this report themselves doubted that wild type FapC might have an impact on $\alpha$-synuclein deposition in the gut due to its rapid self-aggregation, speculation about administering bacteria with such modified proteins might be nevertheless warranted. Additionally, significant amyloid release from E. coli biofilms upon induction by prophages has been described which might contribute to development of Type 1 diabetes-associated autoimmunity in children [103]. The stimulus leading to prophage induction has not been identified yet; however, this might open up new avenues for controlling curli-release also in people at risk for developing neurodegenerative diseases.

Interestingly, the green tea polyphenol epigallocatechin-3-gallate (EGCG), which has been tested as a therapeutic drug in AD and PD in animal models but also in patients [104], shows anti-amyloidogenic properties also on bacterial biofilms [105]. This indicates that these biofilms might also serve as simple models for identifying and investigating amyloid-destabilizing drugs for human use.

\section{Conclusions}

Potentially, many more amyloids will in future be identified in microorganisms. A proteomics approach in different yeast strains e.g., revealed 33 amyloid-like detergent-resistant proteins in Saccharomyces cerevisiae [106]. Moreover, further functional amyloids still may have to be identified in mammals (for a recent example: RNA-binding protein FXR1, [107]). Some of the microbial amyloid producers are physiological commensals that have a continuous impact on our health status and some might represent occasionally occurring pathogens that could promote amyloid deposition in the human body. As the human amyloids partially have been shown to act anti-microbial, future investigations will have to consider this as an additional aspect in unravelling the gut-microbiota-brain axis in human amyloidoses.

Funding: The author appreciates the support by the Alfons Geib-Stiftung for Alzheimer's disease research.

Acknowledgments: The help of Francesco Valeri providing exemplary plaque-staining within mouse brain and of Mareike Keßler for staining of bacterial biofilm (both: Department of Psychiatry and Psychotherapy, University Medical Center JGU Mainz) is appreciated.

Conflicts of Interest: The author declares no conflict of interest. The funders had no role in the design of the study, in the collection, analyses, or interpretation of data, in the writing of the manuscript, or in the decision to publish the results.

\section{References}

1. Otzen, D.; Riek, R. Functional Amyloids. Cold Spring Harb. Perspect. Biol. 2019, 11. [CrossRef] [PubMed]

2. Bissig, C.; Rochin, L.; van Niel, G. PMEL Amyloid Fibril Formation: The Bright Steps of Pigmentation. Int. J. Mol. Sci. 2016, 17, 1438. [CrossRef] [PubMed]

3. Li, J.; McQuade, T.; Siemer, A.B.; Napetschnig, J.; Moriwaki, K.; Hsiao, Y.S.; Damko, E.; Moquin, D.; Walz, T.; McDermott, A.; et al. The RIP1/RIP3 necrosome forms a functional amyloid signaling complex required for programmed necrosis. Cell 2012, 150, 339-350. [CrossRef]

4. $\quad$ Lin, Q.S.; Chen, P.; Wang, W.X.; Lin, C.C.; Zhou, Y.; Yu, L.H.; Lin, Y.X.; Xu, Y.F.; Kang, D.Z. RIP1/RIP3/MLKL mediates dopaminergic neuron necroptosis in a mouse model of Parkinson disease. Lab. Investig. 2019. [CrossRef] [PubMed]

5. Chiti, F.; Dobson, C.M. Protein Misfolding, Amyloid Formation, and Human Disease: A Summary of Progress over the Last Decade. Annu. Rev. Biochem. 2017, 86, 27-68. [CrossRef] [PubMed] 
6. Joy, T.; Wang, J.; Hahn, A.; Hegele, R.A. APOA1 related amyloidosis: A case report and literature review. Clin. Biochem. 2003, 36, 641-645. [CrossRef]

7. Granel, B.; Valleix, S.; Serratrice, J.; Cherin, P.; Texeira, A.; Disdier, P.; Weiller, P.J.; Grateau, G. Lysozyme amyloidosis: Report of 4 cases and a review of the literature. Medicine (Baltimore) 2006, 85, 66-73. [CrossRef]

8. Scheltens, P.; Blennow, K.; Breteler, M.M.; de Strooper, B.; Frisoni, G.B.; Salloway, S.; Van der Flier, W.M. Alzheimer's disease. Lancet 2016, 388, 505-517. [CrossRef]

9. Dorsey, E.R.; Sherer, T.; Okun, M.S.; Bloem, B.R. The Emerging Evidence of the Parkinson Pandemic. J. Parkinsons Dis. 2018, 8, S3-S8. [CrossRef]

10. Endres, K.; Schafer, K.H. Influence of Commensal Microbiota on the Enteric Nervous System and Its Role in Neurodegenerative Diseases. J. Innate Immun. 2018, 10, 172-180. [CrossRef]

11. Santos, S.F.; de Oliveira, H.L.; Yamada, E.S.; Neves, B.C.; Pereira, A., Jr. The Gut and Parkinson's Disease-A Bidirectional Pathway. Front. Neurol. 2019, 10, 574. [CrossRef] [PubMed]

12. D'Argenio, V.; Sarnataro, D. Microbiome Influence in the Pathogenesis of Prion and Alzheimer's Diseases. Int. J. Mol. Sci. 2019, 20, 4704. [CrossRef] [PubMed]

13. Scheperjans, F.; Derkinderen, P.; Borghammer, P. The Gut and Parkinson's Disease: Hype or Hope? J. Parkinsons Dis. 2018, 8, S31-S39. [CrossRef] [PubMed]

14. Scheperjans, F.; Aho, V.; Pereira, P.A.; Koskinen, K.; Paulin, L.; Pekkonen, E.; Haapaniemi, E.; Kaakkola, S.; Eerola-Rautio, J.; Pohja, M.; et al. Gut microbiota are related to Parkinson's disease and clinical phenotype. Mov. Disord. 2015, 30, 350-358. [CrossRef]

15. Keshavarzian, A.; Green, S.J.; Engen, P.A.; Voigt, R.M.; Naqib, A.; Forsyth, C.B.; Mutlu, E.; Shannon, K.M. Colonic bacterial composition in Parkinson's disease. Mov. Disord. 2015, 30, 1351-1360. [CrossRef]

16. Unger, M.M.; Spiegel, J.; Dillmann, K.U.; Grundmann, D.; Philippeit, H.; Burmann, J.; Fassbender, K.; Schwiertz, A.; Schafer, K.H. Short chain fatty acids and gut microbiota differ between patients with Parkinson's disease and age-matched controls. Parkinsonism Relat. Disord. 2016, 32, 66-72. [CrossRef]

17. Bedarf, J.R.; Hildebrand, F.; Coelho, L.P.; Sunagawa, S.; Bahram, M.; Goeser, F.; Bork, P.; Wullner, U. Functional implications of microbial and viral gut metagenome changes in early stage L-DOPA-naive Parkinson's disease patients. Genome Med. 2017, 9, 39. [CrossRef]

18. Heintz-Buschart, A.; Pandey, U.; Wicke, T.; Sixel-Doring, F.; Janzen, A.; Sittig-Wiegand, E.; Trenkwalder, C.; Oertel, W.H.; Mollenhauer, B.; Wilmes, P. The nasal and gut microbiome in Parkinson's disease and idiopathic rapid eye movement sleep behavior disorder. Mov. Disord. 2018, 33, 88-98. [CrossRef]

19. Endres, K. Retinoic Acid and the Gut Microbiota in Alzheimer's Disease: Fighting Back-to-Back? Curr. Alzheimer Res. 2019, 16, 405-417. [CrossRef]

20. Sun, M.F.; Zhu, Y.L.; Zhou, Z.L.; Jia, X.B.; Xu, Y.D.; Yang, Q.; Cui, C.; Shen, Y.Q. Neuroprotective effects of fecal microbiota transplantation on MPTP-induced Parkinson's disease mice: Gut microbiota, glial reaction and TLR4/TNF-alpha signaling pathway. Brain Behav. Immun. 2018, 70, 48-60. [CrossRef]

21. Sun, J.; Xu, J.; Ling, Y.; Wang, F.; Gong, T.; Yang, C.; Ye, S.; Ye, K.; Wei, D.; Song, Z.; et al. Fecal microbiota transplantation alleviated Alzheimer's disease-like pathogenesis in APP/PS1 transgenic mice. Transl. Psychiatry 2019, 9, 189. [CrossRef] [PubMed]

22. Paiva, I.; Pinho, R.; Pavlou, M.A.; Hennion, M.; Wales, P.; Schutz, A.L.; Rajput, A.; Szego, E.M.; Kerimoglu, C.; Gerhardt, E.; et al. Sodium butyrate rescues dopaminergic cells from alpha-synuclein-induced transcriptional deregulation and DNA damage. Hum. Mol. Genet. 2017, 26, 2231-2246. [CrossRef] [PubMed]

23. Kong, Y.; Jiang, B.; Luo, X. Gut microbiota influences Alzheimer's disease pathogenesis by regulating acetate in Drosophila model. Future Microbiol. 2018, 13, 1117-1128. [CrossRef] [PubMed]

24. Oakley, H.; Cole, S.L.; Logan, S.; Maus, E.; Shao, P.; Craft, J.; Guillozet-Bongaarts, A.; Ohno, M.; Disterhoft, J.; Van Eldik, L.; et al. Intraneuronal beta-amyloid aggregates, neurodegeneration, and neuron loss in transgenic mice with five familial Alzheimer's disease mutations: Potential factors in amyloid plaque formation. J. Neurosci. 2006, 26, 10129-10140. [CrossRef] [PubMed]

25. Zhan, X.; Stamova, B.; Sharp, F.R. Lipopolysaccharide Associates with Amyloid Plaques, Neurons and Oligodendrocytes in Alzheimer's Disease Brain: A Review. Front. Aging Neurosci. 2018, 10, 42. [CrossRef]

26. Miklossy, J. Alzheimer's disease-A neurospirochetosis. Analysis of the evidence following Koch's and Hill's criteria. J. Neuroinflammation 2011, 8, 90. [CrossRef]

27. Lionnet, A.; Leclair-Visonneau, L.; Neunlist, M.; Murayama, S.; Takao, M.; Adler, C.H.; Derkinderen, P.; Beach, T.G. Does Parkinson's disease start in the gut? Acta Neuropathol. 2018, 135, 1-12. [CrossRef] 
28. Brandscheid, C.; Schuck, F.; Reinhardt, S.; Schafer, K.H.; Pietrzik, C.U.; Grimm, M.; Hartmann, T.; Schwiertz, A.; Endres, K. Altered Gut Microbiome Composition and Tryptic Activity of the 5xFAD Alzheimer's Mouse Model. J. Alzheimers Dis. 2017, 56, 775-788. [CrossRef]

29. Joachim, C.L.; Mori, H.; Selkoe, D.J. Amyloid beta-protein deposition in tissues other than brain in Alzheimer's disease. Nature 1989, 341, 226-230. [CrossRef]

30. Park, S.C.; Moon, J.C.; Shin, S.Y.; Son, H.; Jung, Y.J.; Kim, N.H.; Kim, Y.M.; Jang, M.K.; Lee, J.R. Functional characterization of alpha-synuclein protein with antimicrobial activity. Biochem. Biophys. Res. Commun. 2016, 478, 924-928. [CrossRef]

31. Spitzer, P.; Condic, M.; Herrmann, M.; Oberstein, T.J.; Scharin-Mehlmann, M.; Gilbert, D.F.; Friedrich, O.; Gromer, T.; Kornhuber, J.; Lang, R.; et al. Amyloidogenic amyloid-beta-peptide variants induce microbial agglutination and exert antimicrobial activity. Sci. Rep. 2016, 6, 32228. [CrossRef] [PubMed]

32. Soscia, S.J.; Kirby, J.E.; Washicosky, K.J.; Tucker, S.M.; Ingelsson, M.; Hyman, B.; Burton, M.A.; Goldstein, L.E.; Duong, S.; Tanzi, R.E.; et al. The Alzheimer's disease-associated amyloid beta-protein is an antimicrobial peptide. PLoS ONE 2010, 5, e9505. [CrossRef] [PubMed]

33. Liang, K.J.; Carlson, E.S. Resistance, vulnerability and resilience: A review of the cognitive cerebellum in aging and neurodegenerative diseases. Neurobiol. Learn. Mem. 2019. [CrossRef] [PubMed]

34. Kumar, D.K.; Choi, S.H.; Washicosky, K.J.; Eimer, W.A.; Tucker, S.; Ghofrani, J.; Lefkowitz, A.; McColl, G.; Goldstein, L.E.; Tanzi, R.E.; et al. Amyloid-beta peptide protects against microbial infection in mouse and worm models of Alzheimer's disease. Sci. Transl. Med. 2016, 8, 340ra372. [CrossRef] [PubMed]

35. Gosztyla, M.L.; Brothers, H.M.; Robinson, S.R. Alzheimer's Amyloid-beta is an Antimicrobial Peptide: A Review of the Evidence. J. Alzheimers Dis. 2018, 62, 1495-1506. [CrossRef]

36. Erickson, M.A.; Banks, W.A. Age-Associated Changes in the Immune System and Blood(-)Brain Barrier Functions. Int. J. Mol. Sci. 2019, 20, 1632. [CrossRef]

37. Gerhardt, S.; Mohajeri, M.H. Changes of Colonic Bacterial Composition in Parkinson's Disease and Other Neurodegenerative Diseases. Nutrients 2018, 10, 708. [CrossRef]

38. Fowler, D.M.; Koulov, A.V.; Alory-Jost, C.; Marks, M.S.; Balch, W.E.; Kelly, J.W. Functional amyloid formation within mammalian tissue. PLoS Biol. 2006, 4, e6. [CrossRef]

39. Maji, S.K.; Perrin, M.H.; Sawaya, M.R.; Jessberger, S.; Vadodaria, K.; Rissman, R.A.; Singru, P.S.; Nilsson, K.P.; Simon, R.; Schubert, D.; et al. Functional amyloids as natural storage of peptide hormones in pituitary secretory granules. Science 2009, 325, 328-332. [CrossRef]

40. Whelly, S.; Johnson, S.; Powell, J.; Borchardt, C.; Hastert, M.C.; Cornwall, G.A. Nonpathological extracellular amyloid is present during normal epididymal sperm maturation. PLoS ONE 2012, 7, e36394. [CrossRef]

41. Greenwald, J.; Kwiatkowski, W.; Riek, R. Peptide Amyloids in the Origin of Life. J. Mol. Biol. 2018, 430, 3735-3750. [CrossRef] [PubMed]

42. Costerton, J.W.; Geesey, G.G.; Cheng, K.J. How bacteria stick. Sci. Am. 1978, 238, 86-95. [CrossRef] [PubMed]

43. Guttenplan, S.B.; Kearns, D.B. Regulation of flagellar motility during biofilm formation. FEMS Microbiol. Rev. 2013, 37, 849-871. [CrossRef] [PubMed]

44. Okshevsky, M.; Meyer, R.L. The role of extracellular DNA in the establishment, maintenance and perpetuation of bacterial biofilms. Crit Rev. Microbiol. 2015, 41, 341-352. [CrossRef] [PubMed]

45. Serra, D.O.; Hengge, R. A c-di-GMP-Based Switch Controls Local Heterogeneity of Extracellular Matrix Synthesis which Is Crucial for Integrity and Morphogenesis of Escherichia coli Macrocolony Biofilms. J. Mol. Biol. 2019, 431, 4775-4793. [CrossRef] [PubMed]

46. Zogaj, X.; Bokranz, W.; Nimtz, M.; Romling, U. Production of cellulose and curli fimbriae by members of the family Enterobacteriaceae isolated from the human gastrointestinal tract. Infect. Immun. 2003, 71, 4151-4158. [CrossRef]

47. Louros, N.N.; Bolas, G.M.P.; Tsiolaki, P.L.; Hamodrakas, S.J.; Iconomidou, V.A. Intrinsic aggregation propensity of the CsgB nucleator protein is crucial for curli fiber formation. J. Struct. Biol. 2016, 195, 179-189. [CrossRef]

48. Hammer, N.D.; Schmidt, J.C.; Chapman, M.R. The curli nucleator protein, CsgB, contains an amyloidogenic domain that directs CsgA polymerization. Proc. Natl. Acad. Sci. USA 2007, 104, 12494-12499. [CrossRef]

49. Dueholm, M.S.; Albertsen, M.; Otzen, D.; Nielsen, P.H. Curli functional amyloid systems are phylogenetically widespread and display large diversity in operon and protein structure. PLoS ONE 2012, 7, e51274. [CrossRef] 
50. Brombacher, E.; Baratto, A.; Dorel, C.; Landini, P. Gene expression regulation by the Curli activator CsgD protein: Modulation of cellulose biosynthesis and control of negative determinants for microbial adhesion. J. Bacteriol. 2006, 188, 2027-2037. [CrossRef]

51. Larsen, P.; Nielsen, J.L.; Dueholm, M.S.; Wetzel, R.; Otzen, D.; Nielsen, P.H. Amyloid adhesins are abundant in natural biofilms. Environ. Microbiol. 2007, 9, 3077-3090. [CrossRef] [PubMed]

52. Cimdins, A.; Simm, R. Semiquantitative Analysis of the Red, Dry, and Rough Colony Morphology of Salmonella enterica Serovar Typhimurium and Escherichia coli Using Congo Red. Methods Mol. Biol. 2017, 1657, 225-241. [CrossRef]

53. Goulter-Thorsen, R.M.; Taran, E.; Gentle, I.R.; Gobius, K.S.; Dykes, G.A. CsgA Production by Escherichia coli O157:H7 Alters Attachment to Abiotic Surfaces in Some Growth Environments. Appl. Environ. Microb. 2011, 77, 7339-7344. [CrossRef] [PubMed]

54. Oh, Y.J.; Hubauer-Brenner, M.; Gruber, H.J.; Cui, Y.D.; Traxler, L.; Siligan, C.; Park, S.; Hinterdorfer, P. Curli mediate bacterial adhesion to fibronectin via tensile multiple bonds. Sci. Rep. 2016, 6. [CrossRef] [PubMed]

55. Gophna, U.; Oelschlaeger, T.A.; Hacker, J.; Ron, E.Z. Role of fibronectin in curli-mediated internalization. FEMS Microbiol. Lett. 2002, 212, 55-58. [CrossRef] [PubMed]

56. Kock, R.; Becker, K.; Cookson, B.; van Gemert-Pijnen, J.E.; Harbarth, S.; Kluytmans, J.; Mielke, M.; Peters, G.; Skov, R.L.; Struelens, M.J.; et al. Methicillin-resistant Staphylococcus aureus (MRSA): Burden of disease and control challenges in Europe. Euro Surveill 2010, 15, 19688. [CrossRef] [PubMed]

57. Khorasani, M.R.; Zamanzad, B.; Rostami, S.; Gholipour, A. High prevalence of SCC mec-associated Phenol-soluble modulin gene in clinical isolates of methicillin-resistant Staphylococcus aureus. Ann. Ig 2019, 31, 148-155. [CrossRef]

58. Tayeb-Fligelman, E.; Tabachnikov, O.; Moshe, A.; Goldshmidt-Tran, O.; Sawaya, M.R.; Coquelle, N.; Colletier, J.P.; Landau, M. The cytotoxic Staphylococcus aureus PSMalpha3 reveals a cross-alpha amyloid-like fibril. Science 2017, 355, 831-833. [CrossRef]

59. Salinas, N.; Colletier, J.P.; Moshe, A.; Landau, M. Extreme amyloid polymorphism in Staphylococcus aureus virulent PSMalpha peptides. Nat. Commun. 2018, 9, 3512. [CrossRef]

60. Sztukowska, M.N.; Dutton, L.C.; Delaney, C.; Ramsdale, M.; Ramage, G.; Jenkinson, H.F.; Nobbs, A.H.; Lamont, R.J. Community Development between Porphyromonas gingivalis and Candida albicans Mediated by InlJ and Als3. mBio 2018, 9. [CrossRef]

61. Saif, Y.M. Immunosuppression induced by infectious bursal disease virus. Vet. Immunol. Immunopathol. 1991, 30, 45-50. [CrossRef]

62. Zheng, X.; Jia, L.; Hu, B.; Sun, Y.; Zhang, Y.; Gao, X.; Deng, T.; Bao, S.; Xu, L.; Zhou, J. The C-terminal amyloidogenic peptide contributes to self-assembly of Avibirnavirus viral protease. Sci. Rep. 2015, 5, 14794. [CrossRef]

63. Ohnishi, S.; Koide, A.; Koide, S. Solution conformation and amyloid-like fibril formation of a polar peptide derived from a beta-hairpin in the OspA single-layer beta-sheet. J. Mol. Biol. 2000, 301, 477-489. [CrossRef] [PubMed]

64. Malabirade, A.; Morgado-Brajones, J.; Trepout, S.; Wien, F.; Marquez, I.; Seguin, J.; Marco, S.; Velez, M.; Arluison, V. Membrane association of the bacterial riboregulator Hfq and functional perspectives. Sci. Rep. 2017, 7, 10724. [CrossRef] [PubMed]

65. Chiang, Y.L.; Chang, Y.C.; Chiang, I.C.; Mak, H.M.; Hwang, I.S.; Shih, Y.L. Atomic Force Microscopy Characterization of Protein Fibrils Formed by the Amyloidogenic Region of the Bacterial Protein MinE on Mica and a Supported Lipid Bilayer. PLoS ONE 2015, 10, e0142506. [CrossRef] [PubMed]

66. Hsieh, C.W.; Lin, T.Y.; Lai, H.M.; Lin, C.C.; Hsieh, T.S.; Shih, Y.L. Direct MinE-membrane interaction contributes to the proper localization of MinDE in E. coli. Mol. Microbiol. 2010, 75, 499-512. [CrossRef] [PubMed]

67. Canale, C.; Torrassa, S.; Rispoli, P.; Relini, A.; Rolandi, R.; Bucciantini, M.; Stefani, M.; Gliozzi, A. Natively folded HypF-N and its early amyloid aggregates interact with phospholipid monolayers and destabilize supported phospholipid bilayers. Biophys. J. 2006, 91, 4575-4588. [CrossRef]

68. Hammer, N.D.; McGuffie, B.A.; Zhou, Y.; Badtke, M.P.; Reinke, A.A.; Brannstrom, K.; Gestwicki, J.E.; Olofsson, A.; Almqvist, F.; Chapman, M.R. The C-terminal repeating units of CsgB direct bacterial functional amyloid nucleation. J. Mol. Biol. 2012, 422, 376-389. [CrossRef] 
69. Lopez-Ochoa, J.; Montes-Garcia, J.F.; Vazquez, C.; Sanchez-Alonso, P.; Perez-Marquez, V.M.; Blackall, P.J.; Vaca, S.; Negrete-Abascal, E. Gallibacterium elongation factor-Tu possesses amyloid-like protein characteristics, participates in cell adhesion, and is present in biofilms. J. Microbiol. 2017, 55, 745-752. [CrossRef]

70. Montes Garcia, J.F.; Vaca, S.; Delgado, N.L.; Uribe-Garcia, A.; Vazquez, C.; Sanchez Alonso, P.; Xicohtencatl Cortes, J.; Cruz Cordoba, A.; Negrete Abascal, E. Mannheimia haemolytica OmpP2-like is an amyloid-like protein, forms filaments, takes part in cell adhesion and is part of biofilms. Antonie Van Leeuwenhoek 2018, 111, 2311-2321. [CrossRef]

71. Wang, L.; Maji, S.K.; Sawaya, M.R.; Eisenberg, D.; Riek, R. Bacterial inclusion bodies contain amyloid-like structure. PLoS Biol. 2008, 6, e195. [CrossRef] [PubMed]

72. Conrad, W.H.; Osman, M.M.; Shanahan, J.K.; Chu, F.; Takaki, K.K.; Cameron, J.; Hopkinson-Woolley, D.; Brosch, R.; Ramakrishnan, L. Mycobacterial ESX-1 secretion system mediates host cell lysis through bacterium contact-dependent gross membrane disruptions. Proc. Natl. Acad. Sci. USA 2017, 114, 1371-1376. [CrossRef] [PubMed]

73. Bleem, A.; Christiansen, G.; Madsen, D.J.; Maric, H.; Stromgaard, K.; Bryers, J.D.; Daggett, V.; Meyer, R.L.; Otzen, D.E. Protein Engineering Reveals Mechanisms of Functional Amyloid Formation in Pseudomonas aeruginosa Biofilms. J. Mol. Biol. 2018, 430, 3751-3763. [CrossRef] [PubMed]

74. Zeng, G.; Vad, B.S.; Dueholm, M.S.; Christiansen, G.; Nilsson, M.; Tolker-Nielsen, T.; Nielsen, P.H.; Meyer, R.L.; Otzen, D.E. Functional bacterial amyloid increases Pseudomonas biofilm hydrophobicity and stiffness. Front. Microbiol. 2015, 6, 1099. [CrossRef] [PubMed]

75. Marinelli, P.; Pallares, I.; Navarro, S.; Ventura, S. Dissecting the contribution of Staphylococcus aureus alpha-phenol-soluble modulins to biofilm amyloid structure. Sci. Rep. 2016, 6, 34552. [CrossRef] [PubMed]

76. Schwartz, K.; Sekedat, M.D.; Syed, A.K.; O’Hara, B.; Payne, D.E.; Lamb, A.; Boles, B.R. The AgrD N-terminal leader peptide of Staphylococcus aureus has cytolytic and amyloidogenic properties. Infect. Immun. 2014, 82, 3837-3844. [CrossRef] [PubMed]

77. Lembre, P.; Vendrely, C.; Martino, P.D. Identification of an amyloidogenic peptide from the Bap protein of Staphylococcus epidermidis. Protein Pept. Lett. 2014, 21, 75-79. [CrossRef]

78. Lin, J.; Oh, S.H.; Jones, R.; Garnett, J.A.; Salgado, P.S.; Rusnakova, S.; Matthews, S.J.; Hoyer, L.L.; Cota, E. The peptide-binding cavity is essential for Als3-mediated adhesion of Candida albicans to human cells. J. Biol. Chem. 2014, 289, 18401-18412. [CrossRef]

79. Selivanova, O.M.; Glyakina, A.V.; Gorbunova, E.Y.; Mustaeva, L.G.; Suvorina, M.Y.; Grigorashvili, E.I.; Nikulin, A.D.; Dovidchenko, N.V.; Rekstina, V.V.; Kalebina, T.S.; et al. Structural model of amyloid fibrils for amyloidogenic peptide from Bgl2p-glucantransferase of $S$. cerevisiae cell wall and its modifying analog. New morphology of amyloid fibrils. Biochim. Biophys. Acta 2016, 1864, 1489-1499. [CrossRef]

80. Zhang, S.M.; Liao, Y.; Neo, T.L.; Lu, Y.; Liu, D.X.; Vahlne, A.; Tam, J.P. Identification and application of self-binding zipper-like sequences in SARS-CoV spike protein. Int. J. Biochem. Cell Biol. 2018, 101, 103-112. [CrossRef]

81. Ulusoy, A.; Rusconi, R.; Perez-Revuelta, B.I.; Musgrove, R.E.; Helwig, M.; Winzen-Reichert, B.; Di Monte, D.A. Caudo-rostral brain spreading of alpha-synuclein through vagal connections. EMBO Mol. Med. 2013, 5, 1119-1127. [CrossRef] [PubMed]

82. Suarez, A.N.; Hsu, T.M.; Liu, C.M.; Noble, E.E.; Cortella, A.M.; Nakamoto, E.M.; Hahn, J.D.; de Lartigue, G.; Kanoski, S.E. Gut vagal sensory signaling regulates hippocampus function through multi-order pathways. Nat. Commun. 2018, 9, 2181. [CrossRef] [PubMed]

83. Rinaman, L. Ascending projections from the caudal visceral nucleus of the solitary tract to brain regions involved in food intake and energy expenditure. Brain Res. 2010, 1350, 18-34. [CrossRef] [PubMed]

84. Grill, H.J.; Hayes, M.R. Hindbrain neurons as an essential hub in the neuroanatomically distributed control of energy balance. Cell Metab. 2012, 16, 296-309. [CrossRef]

85. Liu, B.; Fang, F.; Pedersen, N.L.; Tillander, A.; Ludvigsson, J.F.; Ekbom, A.; Svenningsson, P.; Chen, H.; Wirdefeldt, K. Vagotomy and Parkinson disease: A Swedish register-based matched-cohort study. Neurology 2017, 88, 1996-2002. [CrossRef]

86. Uemura, N.; Yagi, H.; Uemura, M.T.; Hatanaka, Y.; Yamakado, H.; Takahashi, R. Inoculation of alpha-synuclein preformed fibrils into the mouse gastrointestinal tract induces Lewy body-like aggregates in the brainstem via the vagus nerve. Mol. Neurodegener. 2018, 13, 21. [CrossRef] 
87. Kaatz, M.; Fast, C.; Ziegler, U.; Balkema-Buschmann, A.; Hammerschmidt, B.; Keller, M.; Oelschlegel, A.; McIntyre, L.; Groschup, M.H. Spread of classic BSE prions from the gut via the peripheral nervous system to the brain. Am. J. Pathol. 2012, 181, 515-524. [CrossRef]

88. Marshall, A.; Bradford, B.M.; Clarke, A.R.; Manson, J.C.; Mabbott, N.A. Oral Prion Neuroinvasion Occurs Independently of $\operatorname{PrP}(\mathrm{C})$ Expression in the Gut Epithelium. J. Virol. 2018, 92. [CrossRef]

89. Endres, K.; Reinhardt, S.; Geladaris, A.; Knies, J.; Grimm, M.; Hartmann, T.; Schmitt, U. Transnasal delivery of human A-beta peptides elicits impaired learning and memory performance in wild type mice. BMC Neurosci. 2016, 17, 44. [CrossRef]

90. Chen, S.G.; Stribinskis, V.; Rane, M.J.; Demuth, D.R.; Gozal, E.; Roberts, A.M.; Jagadapillai, R.; Liu, R.; Choe, K.; Shivakumar, B.; et al. Exposure to the Functional Bacterial Amyloid Protein Curli Enhances Alpha-Synuclein Aggregation in Aged Fischer 344 Rats and Caenorhabditis elegans. Sci. Rep. 2016, 6, 34477. [CrossRef]

91. Sampson, T.R.; Challis, C.; Jain, N.; Moiseyenko, A.; Ladinsky, M.S.; Shastri, G.G.; Thron, T.; Needham, B.D.; Horvath, I.; Debelius, J.W.; et al. A gut bacterial amyloid promotes alpha-synuclein aggregation and motor impairment in mice. Elife 2020, 9. [CrossRef] [PubMed]

92. Tatini, F.; Pugliese, A.M.; Traini, C.; Niccoli, S.; Maraula, G.; Ed Dami, T.; Mannini, B.; Scartabelli, T.; Pedata, F.; Casamenti, F.; et al. Amyloid-beta oligomer synaptotoxicity is mimicked by oligomers of the model protein HypF-N. Neurobiol. Aging 2013, 34, 2100-2109. [CrossRef] [PubMed]

93. Esfandiary, E.; Karimipour, M.; Mardani, M.; Ghanadian, M.; Alaei, H.A.; Mohammadnejad, D.; Esmaeili, A. Neuroprotective effects of Rosa damascena extract on learning and memory in a rat model of amyloid-beta-induced Alzheimer's disease. Adv. Biomed. Res. 2015, 4, 131. [CrossRef] [PubMed]

94. Nimgampalle, M.; Kuna, Y. Anti-Alzheimer Properties of Probiotic, Lactobacillus plantarum MTCC 1325 in Alzheimer's Disease induced Albino Rats. J. Clin. Diagn. Res. 2017, 11, KC01-KC05. [CrossRef]

95. Kobayashi, Y.; Sugahara, H.; Shimada, K.; Mitsuyama, E.; Kuhara, T.; Yasuoka, A.; Kondo, T.; Abe, K.; Xiao, J.Z. Therapeutic potential of Bifidobacterium breve strain A1 for preventing cognitive impairment in Alzheimer's disease. Sci. Rep. 2017, 7, 13510. [CrossRef]

96. Bonfili, L.; Cecarini, V.; Cuccioloni, M.; Angeletti, M.; Berardi, S.; Scarpona, S.; Rossi, G.; Eleuteri, A.M. SLAB51 Probiotic Formulation Activates SIRT1 Pathway Promoting Antioxidant and Neuroprotective Effects in an AD Mouse Model. Mol. Neurobiol. 2018, 55, 7987-8000. [CrossRef]

97. Athari Nik Azm, S.; Djazayeri, A.; Safa, M.; Azami, K.; Ahmadvand, B.; Sabbaghziarani, F.; Sharifzadeh, M.; Vafa, M. Lactobacilli and bifidobacteria ameliorate memory and learning deficits and oxidative stress in beta-amyloid (1-42) injected rats. Appl. Physiol. Nutr. Metab. 2018, 43, 718-726. [CrossRef]

98. Rezaei Asl,Z.; Sepehri, G.; Salami, M. Probiotic treatment improves the impaired spatial cognitive performance and restores synaptic plasticity in an animal model of Alzheimer's disease. Behav. Brain Res. 2019, 376, 112183. [CrossRef]

99. Rezaeiasl, Z.; Salami, M.; Sepehri, G. The Effects of Probiotic Lactobacillus and Bifidobacterium Strains on Memory and Learning Behavior, Long-Term Potentiation (LTP), and Some Biochemical Parameters in beta-Amyloid-Induced Rat's Model of Alzheimer's Disease. Prev. Nutr. Food Sci. 2019, 24, 265-273. [CrossRef]

100. Leblhuber, F.; Steiner, K.; Schuetz, B.; Fuchs, D.; Gostner, J.M. Probiotic Supplementation in Patients with Alzheimer's Dementia-An Explorative Intervention Study. Curr. Alzheimer Res. 2018, 15, 1106-1113. [CrossRef]

101. Jiang, X.; Yan, X.; Gu, S.; Yang, Y.; Zhao, L.; He, X.; Chen, H.; Ge, J.; Liu, D. Biosurfactants of Lactobacillus helveticus for biodiversity inhibit the biofilm formation of Staphylococcus aureus and cell invasion. Future Microbiol. 2019, 14, 1133-1146. [CrossRef] [PubMed]

102. Christensen, L.F.B.; Jensen, K.F.; Nielsen, J.; Vad, B.S.; Christiansen, G.; Otzen, D.E. Reducing the Amyloidogenicity of Functional Amyloid Protein FapC Increases Its Ability To Inhibit alpha-Synuclein Fibrillation. ACS Omega 2019, 4, 4029-4039. [CrossRef] [PubMed]

103. Tetz, G.; Brown, S.M.; Hao, Y.; Tetz, V. Type 1 Diabetes: An Association between Autoimmunity, the Dynamics of Gut Amyloid-producing E. coli and Their Phages. Sci. Rep. 2019, 9, 9685. [CrossRef] [PubMed]

104. Pervin, M.; Unno, K.; Ohishi, T.; Tanabe, H.; Miyoshi, N.; Nakamura, Y. Beneficial Effects of Green Tea Catechins on Neurodegenerative Diseases. Molecules 2018, 23, 1297. [CrossRef] [PubMed] 
105. Hengge, R. Targeting Bacterial Biofilms by the Green Tea Polyphenol EGCG. Molecules 2019, $24,2403$. [CrossRef]

106. Ryzhova, T.A.; Sopova, J.V.; Zadorsky, S.P.; Siniukova, V.A.; Sergeeva, A.V.; Galkina, S.A.; Nizhnikov, A.A.; Shenfeld, A.A.; Volkov, K.V.; Galkin, A.P. Screening for amyloid proteins in the yeast proteome. Curr. Genet. 2018, 64, 469-478. [CrossRef]

107. Sopova, J.V.; Koshel, E.I.; Belashova, T.A.; Zadorsky, S.P.; Sergeeva, A.V.; Siniukova, V.A.; Shenfeld, A.A.; Velizhanina, M.E.; Volkov, K.V.; Nizhnikov, A.A.; et al. RNA-binding protein FXR1 is presented in rat brain in amyloid form. Sci. Rep. 2019, 9, 18983. [CrossRef]

(C) 2020 by the author. Licensee MDPI, Basel, Switzerland. This article is an open access article distributed under the terms and conditions of the Creative Commons Attribution (CC BY) license (http://creativecommons.org/licenses/by/4.0/). 